\title{
ПЕРСПЕКТИВИ ВИКОРИСТАННЯ SМАRT-СТРАТЕГІЇ В РОЗВИТКУ ПІСЛЯДИПЛОМНОї МЕДИЧНОї ОСВІТИ
}

\author{
О. М. Шевцова, Я. О. Шевченко, А. С. Фещенко, \\ Т. Ю. Дубініна, Н. В. Мироненко, Н. О. Сінєнко ${ }^{1}$, \\ П. П. Ганинець², О. В. Сарканич², О. О. Суханова \\ Національна медична академія післядипломної освіти імені П. Л. Шупика \\ ${ }^{1}$ Міністерство охорони здоров'я України \\ ${ }^{2}$ ТОВ «Сузір'я» Санаторій «Квітка полонини»
}

\begin{abstract}
Розглянуто основні принципи та перспективи використання нової стратегії освіти, що здобула назву SMART. Показано, що найважливішим принципом медичної післядипломної SMART-освіти є забезпечення її компетентнісної орієнтованості, тобто постійного оновлення змісту навчання. Підкреслюється, що рішення проблем SMART-освіти пов'язано з двома напрямами: визнанням необхідності об'єднання фрормального й інформального навчання та інтелектуалізацією процесів передавання знань.
\end{abstract}

Ключові слова: SMART-стратегія освіти, мобільні технології, освітнє середовище, підготовка лікарів і провізорів, післядипломна медична освіта, безперервний професійний розвиток лікарів і провізорів, формальна й інформальна освіта, міждисциплінарна та трансдисциплінарна освіта, штучний інтелект, нейронні мережі, компетентнісна освіта.

\section{PROSPECTS OF USING THE SMART-STRATEGY IN THE DEVELOPMENT OF POSTGRADUATE MEDICAL EDUCATION}

\author{
O. M. Shevtsova, Ya. O. Shevchenko, A. S. Feshchenko, \\ T. Yu. Dubinina, N. V. Myronenko, N. O. Sinyenko', \\ P. P. Ganynets ${ }^{2}$, O. V. Sarkanych ${ }^{2}$, O. O. Sukhanova \\ Shupyk National Medical Academy of Postgraduate Education \\ ${ }^{1}$ Ministry of Health Care of Ukraine \\ ${ }^{2}$ «Suzir'ya» Ltd Spa resort «Kvitka Polonyny»
}

\begin{abstract}
The main principles and prospects for using the new education strategy, which was named by SMART, are considered. It is shown that the most important principle of medical postgraduate SMART-education is to ensure its competence-oriented orientation, that is, constant updating of the content of training. It is emphasized that the solutions to the problems of SMART education are related to two areas: the recognition of the need to combine formal and informal learning and the intellectualization of knowledge transfer processes.
\end{abstract}

Key words: SMART-education strategy, mobile technologies, educational environment, training of doctors and pharmacists, postgraduate medical education, continuous professional development of doctors and pharmacists, formal and informational education; interdisciplinary and transdisciplinary education; artificial intelligence; neural networks; competence education. 


\title{
ПЕРСПЕКТИВЫ ИСПОЛЬЗОВАНИЯ SМАRT-СТРАТЕГИИ В РАЗВИТИИ ПОСЛЕДИПЛОМНОГО МЕДИЦИНСКОГО ОБРАЗОВАНИЯ
}

\author{
Е. Н. Шевцова, Я. А. Шевченко, А. С. Фещенко, \\ Т. Ю. Дубинина, Н. В. Мироненко, Н. А. Синенко, \\ П. П. Ганинец², А. В. Сарканич², О. А. Суханова \\ Национальная медицинская академия последипломного обучения имени П. Л. Шупика \\ ${ }^{1}$ Министерство здравоохранения Украины \\ 200О «Сузирья» Санаторий «Квитка полоныны»
}

\begin{abstract}
Рассмотрены основные принципы и перспективы использования новой стратегии образования, которая получила название SMART. Показано, что важнейшим принципом медицинского последипломного SMART-образования является обеспечение его компетентностной ориентированности, то есть постоянное обновление содержания обучения. Подчеркивается, что решение проблем SMART-образования связано с двумя направлениями: признанием необходимости объединения фрормального и информального обучения и интеллектуализацией процессов передачи знаний.
\end{abstract}

Ключевые слова: SMART-стратегия образования, мобильные технологии, образовательная среда, подготовка врачей и провизоров, последипломное медицинское образование, непрерывное профессиональное развитие врачей и провизоров, фрормальное и инсрормальное образование; междисциплинарное и трансдисциплинарное образование; искусственный интеллект; нейронные сети; компетентностное образование.

Вступ. Швидкий розвиток інформаційних технологій зумовив появу стратегії SMART, що розглядається як найбільш перспективний напрям руху сучасного суспільства. Дійсно, стрімкий розвиток інформаційних технологій призвів до того, що кожні 72 години відбувається подвоєння інформації. У результаті велика частина освітнього контенту істотно відстає від використовуваних технологій. Особливого значення цей процес набуває в медицині.

Мета дослідження: розроблення та впровадження нових освітніх технологій передавання знань у післядипломній медичній освіті.

Результати та їх обговорення. Акронім SMART об'єднує великі літери від англійських слів: Specific (конкретність); Measurable (вимірність); Attainable (досяжність); Relevant (релевантність); Time-bounded (визначеність в часі). В реальності під SMART-освітою сьогодні розуміється гнучке навчання, що передбачає: наявність великої кількості джерел інформації, максимальної різноманітності форм подачі навчального матеріалу (мультимедіа, - аудіо, відео, графіка), адаптивне навчання у відповідності з рівнем знань і потребами слухача, використання мобільних пристроїв.

Передбачається, що SMART-освіта повинна бути легко керована, щоб забезпечити організацію освіти, гнучкість навчального процесу та інтегрованість із зовнішніми джерелами інформації. Необхідність розвитку інтелектуального освітнього середовища грунтується на достатньому ступені розвитку SMART-технологій та інтенсивності проникнення їх у повсякденне життя.

Отже, головна мета SMART-освіти - створення навчального середовища, що забезпечує високий рівень конкурентоспроможної освіти за рахунок розвитку в учнів знань і навичок сучасного суспільства: співробітництво, комунікацію, соціальну відповідальність, здатність критично мислити, оперативно і якісно вирішувати проблеми. При цьому, зміна стратегії освітнього процесу загострює рішення ще одного завдання - як вчити сучасних педагогів і підвищувати їх кваліфікацію в електронному середовищі зі SMART-технологіями.

Застосування принципу «використання великої кількості джерел інформації» в SMART-освіті передбачає широке використання мобільних технологій передачі та отримання даних. Різкий приплив мобільної техніки визначив один із важливих напрямків в освіті та перепідготовці персоналу у сфері дистанційної освіти, що користується високою затребуваністю. Намітилася тенденція до побудови відкритих для всіх, хто навчається, доступних електронних курсів [5-7].

Зрозуміло, через стислі терміни навчання студентам складно донести всі необхідні їм знання, особливо в плані конкретизації та максимального розділення інформації, що надходить, на основні аспекти та другорядні. Можна вивчати, зберігати і обробляти велику кількість корисної інформації, завдяки поділу її на блоки, розділи тощо. Проте, щоб забезпечити їх ефективне об’єднання i 
обробку, необхідно суворо виконувати послідовні діï.

Крім розширення базових знань, особа, яка навчається по віддаленій системі, отримує додаткові переваги: удосконалюються навички користувача сучасними IKT; знімаються психологічні проблеми, пов'язані з комунікативними якостями людини; зростає позитивна динаміка кар’єрного зростання людей, що прагнуть до оновлення професійних знань і вдосконалення навиків, але не мають можливості регулярно бути присутніми на очних заняттях.

Важливо зауважити, що роботодавці не завжди задоволені використанням класичних дистанційних технологій, вважаючи за краще організацію діяльності з навчання на робочому місці. В якійсь мірі це негативно позначається на подальшому просуванні віртуальної взаємодії.

Підходи до SMART-освіти ще не формалізовані i не стандартизовані. Проте, нами проведені певні дослідження для підготовки консенсусу для узагальнення принципів подібної передачі знань. Ці принципи включають: гнучкість навчання в інтерактивному освітньому середовищі; персоналізацію та адаптацію навчання; вільний доступ до освітнього контенту по всьому світу, інтелектуалізацію передачі знань.

Підкреслимо, що SMART-освіта реалізується 3 використанням технологічних інновацій та Інтернету, який надає тим, хто навчається, можливість набуття професійних компетенцій на основі системного багатовимірного бачення i вивчення дисциплін з урахуванням їх багатоаспектності і безперервного оновлення змісту. Основою такого навчання є створення інтелектуального середовища для безперервного розвитку компетентностей лікарів і провізорів, включаючи заходи формального та інформального процесу навчання, а технічною базою реалізації стає весь наявний парк технічних засобів навчання, що належить як особам, які навчаються, так i навчальним закладам.

Прийнято виділяти основні характеристики SMART-освіти: безшовність (забезпечення сумісності програмного забезпечення, розробленого для різних операційних систем); незалежність від часу та місця отримання інформації, мобільність, повсюдність, безперервність та простота доступу до навчальної інформації; автономність викладача і учня за рахунок використання мобільних пристроїв доступу до навчальної інформації.
У SMART-стратегії освіти приймається необхідним урахування різних мотиваційних моделей; взаємозв' язок між індивідуальними і організаційними цілями роботодавців і навчального закладу, а також гнучке навчання з точки зору переваг та індивідуальних можливостей того, хто навчається. Можливість налаштування навчання під індивідуальні параметри має включати такі показники, як: вихідні знання, набутий досвід і навики; стиль навчання; урахування фізіологічного та психологічного стану в кожен конкретний момент навчання.

Нами узагальнені умови реалізації SMARTосвіти в післядипломній медичній освіті і безперервному професійному розвитку.

Вони стосуються принципово двох проблем. Це, перш за все, визнання необхідності об’єднання формального та інформального навчання i, подруге, інтелектуалізації процесів передачі знань.

Як відомо, інформальна освіта (самоосвіта) передбачає самоорганізоване здобуття особою певних компетентностей, зокрема під час повсякденної діяльності, пов’язаної з професійною, громадською або іншою діяльністю, родиною чи дозвіллям. Кваліфікації та результати навчання, здобуті шляхом формальної та інформальної освіти, можуть бути підтверджені та визнані у системі формальної освіти або у інших випадках, передбачених законодавством України [1]. В медицині інформальна освіта визнається недостатньо. В той же час безперервний професійний розвиток лікаря чи провізора, по суті, повністю не зорієнтований на інформальність. Про це абсолютно вдало підкреслено в [4]: «Обов’ язкова формальна післядипломна освіта (проходження передатестаційного циклу що п’ять років) в Україні переважає над неформальною (клуби, гуртки, товариства) та інформальною (самоосвіта, індивідуальний пізнавальний процес), оскільки останні не підлягають обліку під час проходження атестації. Тим не менше, висока популярність спеціалізованих медичних видань серед респондентів свідчить про активну інформальну освіту лікарів-слухачів».

Стратегія інформальної освіти, взагалі, є загальним терміном для отримання знань за межами стандартного освітнього середовища й пов’язана 3 індивідуальною пізнавальною діяльністю, що супроводжує повсякденне життя і не обов'язково носить цілеспрямований характер. Вона $є$ віддзеркаленням спонтанного процесу за рахунок власної активності індивіда в навколишньому культурно-освітньому середовищі. Саме тому цей 
термін використовують паралельно 3 поняттями «безперервна освіта», «додаткова освіта», «самоосвіта». Беручи до уваги, що відсутність сертифікації часто є ознакою неформальної освіти, на жаль (і зазвичай), інформальна освіта розглядається в опозиції до формальної, що відбувається в рамках офіційних освітніх інститутів і супроводжується врученням офіційно визнаних документів про освіту [1, 2,].

Важливим принципом медичної післядипломної SMART-освіти є її компетентнісна орієнтованість, тобто оновлення іï̈ змісту на основі певних зазначених роботодавцями та іншими зацікавленими сторонами моделей та профілів компетенцій. Це змушує забезпечити можливість безперервного управління компетенціями протягом усього навчального процесу, з одного боку, та впровадження інструментів самодіагностики освітнього середовища для забезпечення стабільного функціонування всіх її елементів. Необхідні також точні метрики для визначення компетентності до та після навчання, що відображають результативність навчання та логіку скорочення її тривалості.

Iснує ще один важливий елемент SMART-освіти для безперервного професійного розвитку лікарів та провізорів. Для реалізації принципу безперервності необхідне впровадження міждисциплінарного та трансдисциплінарного підходів, використання програмного забезпечення для організації навчального процесу, адаптивного до всіх існуючих операційних систем, в тому числі на основі використання хмарних технологій, проектування контенту на основі єдиних стандартів опису даних, наприклад, на основі специфікацій SCORM. Важливо при цьому забезпечити направлення і систематизовані зміни технічної архітектури.

Беручи до уваги логіку самого процесу отримання знань практично з усіх провідних університетів світу, необхідно забезпечити високу швидкість оновлення освітнього контенту за рахунок використання мікромодулів, можливості оновлення контенту з різних пристроїв. Очевидно, що використання інструментів розробки освітнього контенту, що надають можливість створювати об’єкти у форматах пристроїв, використовуваних в інтегрованому інтелектуальному середовищі, повинно здійснюватися з технологіями штучного інтелекту. Останній найчастіше реалізується на базі штучних нейромереж. Великий досвід застосування штучних нейромереж до виявлення взаємозв’язків між різними параметрами показав як можливість компактно висловити дані великої розмірності, так і можливість зворотного процесу - відновлення вихідного набору даних з частини інформації (асоціативна пам’ять). Доведені здатності нейронної мережі до прогнозування, до узагальнень і виділення прихованих залежностей між вхідними та вихідними даними можуть істотно скорегувати навчальний процес.

У класичному застосуванні штучних нейронних мереж є необхідним процес навчання мереж на навчальній вибірці спостережень. Організація такого процесу досить трудомістка і, певною мірою, невдячна. Нами запропоновано використовувати для скорочення часу навчання розроблені онтології знань. Крім того, останнім часом до ітераційних алгоритмів пошуку нейромережевих рішень, для яких не можна нічого гарантувати і не можна повністю автоматизувати навчання, додались не ітераційні алгоритми, що володіють дуже високою стійкістю і дозволяють повністю автоматизувати процес навчання. В результаті обчислювальні системи, засновані на штучних нейронних мережах, стали частково володіти рядом якостей, які притаманні мозку людини: паралелізм обчислень; розподілене представлення інформації та обчислення; здатність до навчання і узагальнення; адаптивність; властивість контекстуальної обробки інформації; толерантність до помилок.

Необхідно особливо підкреслити, що для успішної реалізації SMART-освіти в університеті науково-педагогічним працівникам важливо суворо дотримуватися існуючих інтелектуальних технологій її впровадження, які повинні здійснюватися з урахуванням особистих вимог та переваг того, хто навчається. Для цього необхідно: використовувати індивідуальний графік навчання, підтримувати постійний контакт студента з викладачем, домагатися міцного засвоєння знань, використовувати зручний час та місце навчання [3].

\section{Висновки.}

1. Найважливішим принципом медичної післядипломної SMART-освіти є забезпечення їï компетентнісної орієнтованості, тобто постійного оновлення змісту навчання.

2. Вирішення проблем SMART-освіти пов'язано 3 двома напрямами: визнанням необхідності об'єднання формального й інформального навчання та інтелектуалізацією процесів передавання знань. 


\section{Література.}

1. Горшкова В. В. Взаимодействие формального, неформального и информального образования как современное направление развития человека / В. В. Горшкова // Концепт. - 2014. - Т. 26. C. $176-180$.

2. Мельник С. В. Квалификации в сфере обучения на протяжении всей жизни: как рассматривать профессиональные квалификации, в том числе приобретенные в результате неформального и спонтанного обучения, а также регулируемые профессии в Украине. Должны ли они входить в состав НРК? : аналитический обзор / С. В. Мельник // Европейский фонд образования. - 2015. - 30 с.

3. Сінєнко Н. О. Особливості забезпечення якості підготовки регульованих професій у рамках державно-приватного партнерства в освіті та е-медицині / Н. О. Сінєнко, Г. В. Загорій, С. І. Мохначов // Медична інформатика та інженерія. — 2016. № 3. - С. 23-27.

4. Стрільчук Л. М. Актуальні проблеми післядипломної освіти лікарів загальної практики - сімейної медицини / Л. М. Стрільчук // Актуальні проблеми сучасної медицини. - 2015. - Т. 15, Вип. 4. C. 301-304.

5. Flexner A. Medical education in the United States and Canada / A. Flexner. — New York : The Carnegie foundation for the advancement of teaching, 2010. Bull. 4. - 364 p.

6. Cooke M. Educating physicians: a call for reform of medical school and residency / M. Cooke, D. M. Irby, B. C. O’Brien. - San Francisco : Jossey-Bass, 2010. - 320 p.

7. Kilman D. G. An international collaboratory based on virtual patient records / D. G. Kilman, D. W. Forslund // Communications of the ACM. - 1997. - Vol. 40, No. 8. - P. 110-117.

8. Dev P. Computers in medical education [Electronic resource] / P. Dev, E. P. Hoffer, G. O. Barnett / Eds. E. H. Shortliffe, J. J. Cimino // Biomedical Informatics. Computer Applications in Health Care and Biomedicine. — London : Spriner-Verlag, 2009. — P. 737-762. — Available at: http://mef.med.ufl.edu/ files/2009/10/Computers-in-Medical-Education.pdf.

9. Towards a multi-vendor mobile learning management system / L. Colazzo, A. Molinari, M. Ronchetti, A. Trifonova / Ed. A. Rossett // E-Learn: World Conference on E-Learning in Corporate, Government, Healthcare, and Higher Education (Phoenix, USA, 2003). - P. 2097-2100.

10. Kukulska-Hulme A. Mobile learning: a handbook for educators and trainers / A. Kukulska-Hulme, J. Traxler. — London : Routledge, 2005. - 228 p.

11. Abdulrasol H. Toward more objective teaching learning and teaching / H. Abdulrasol // Medical Journal of Babylon. - 2011. — Vol. 8 , No. 4. — P. 1-7.
12. Krippel G. Multimedia use in higher education: promises and pitfalls / G. Krippel, A. J. McKee, J. Moody // Journal of Instructional Pedagogies. 2010. — Vol. 2. - P. 1-8.

\section{References.}

1. Gorshkova, V. V. (2014). Vzaimodeystviye formal'nogo, neformal'nogo i informal'nogo obrazovaniya kak sovremennoye napravleniye razvitiya cheloveka [The interaction of formal, informal and informational education as a modern direction of human development]. Kontsept, 26, 176-180.

2. Mel’nik, S. V. (2015). Kvalifikatsii v sfere obucheniya na protyazhenii vsey zhizni: kak rassmatrivat' professional'nyye kvalifikatsii, v tom chisle priobretennyye $\mathrm{v}$ rezul'tate neformal'nogo i spontannogo obucheniya, a takzhe reguliruyemyye professii v Ukraine. Dolzhny li oni vkhodit' v sostav NRK? [Qualifications in the field of lifelong learning: how to consider professional qualifications, including those acquired as a result of informal and spontaneous training, as well as regulated professions in Ukraine. Should they be part of the NRC?]: an analytical review. Yevropeyskiy fond obrazovaniya (European Education Foundation).

3. Sinyenko, N. O., Zahori, H. V., \& Mokhnachov, S. I. (2016). Osoblyvosti zabezpechennya yakosti pidhotovky rehul'ovanykh profesiy u ramkakh derzhavnopryvatnoho partnerstva v osviti ta e-medytsyni [Features of quality assurance in the preparation of regulated professions within the framework of public-private partnership in education and e-medicine]. Medychna informatyka ta inzheneriya (Medical Informatics and Engineering), 3, 23-27.

4. Stril'chuk, L. M. (2015). Aktual'ni problemy pislyadyplomnoyi osvity likariv zahal'noyi praktyky — simeynoyi medytsyny [Actual problems of postgraduate education of general practitioners - family medicine. Aktual'ni problemy suchasnoyi medytsyny (Actual Problems of Modern Medicine), 15(4), 301-304.

5. Flexner, A. (2010). Medical education in the United States and Canada. New York: The Carnegie foundation for the advancement of teaching. Bulletin 4.

6. Cooke, M., Irby, D. M., \& O’Brien, B. C. (2010). Educating physicians: a call for reform of medical school and residency. San Francisco: Jossey-Bass.

7. Kilman, D. G., \& Forslund, D. W. (1997). An international collaboratory based on virtual patient records. Communications of the ACM, 40(8), 110-117.

8. Dev, P., Hoffer, E. P., \& Barnett, G. O. (2009). Computers in medical education. In E. H. Shortliffe, J. J. Cimino (Eds.), Biomedical informatics. Computer applications in health care and biomedicine (p. 737762). London: Spriner-Verlag. Retrieved from http:// mef.med.ufl.edu/files/2009/10/Computers-in-MedicalEducation.pdf. 
9. Colazzo, L., Molinari, A., Ronchetti, M., \& Trifonova, A. (2003). Towards a multi-vendor mobile learningmanagement system. In A. Rossett (Ed.) E-Learn: World Conference on E-Learning in Corporate, Government, Healthcare, and Higher Education (pp. 2097-2100). Phoenix, USA.

10. Kukulska-Hulme, A., Traxler, J. (2005) Mobile learning: a handbook for educators and trainers. London: Routledge.

11. Abdulrasol, H. (2011). Toward more objective teaching learning and teaching. Medical Journal of Babylon, 8(4), 1-7.

12. Krippel, G., McKee, A. J., \& Moody, J. (2010). Multimedia use in higher education: promises and pitfalls. Journal of Instructional Pedagogies, 2, 1-8. 